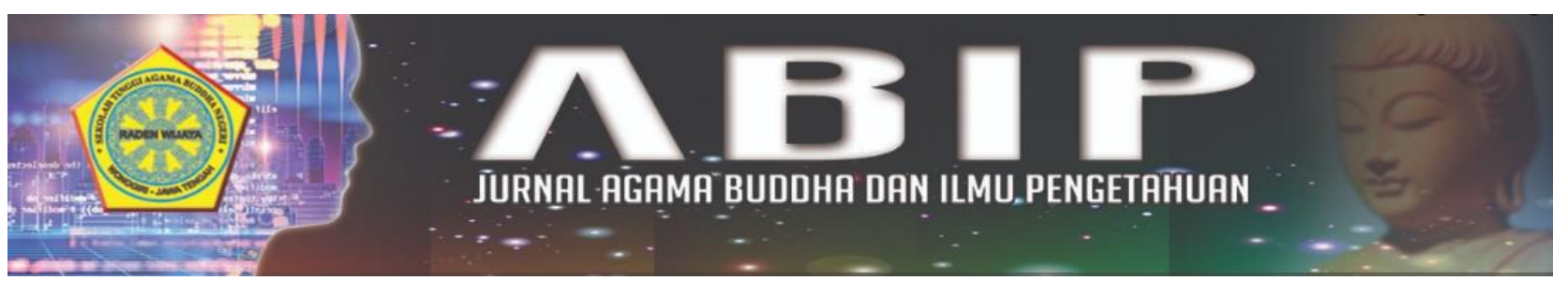

\title{
STUDI EKOLINGUISTIK DALAM DINAMIKA TUTUR BAHASA JAWA RAGAM PERTANIAN PADA MASYARAKAT BUDDHA DI DUSUN GUNUNG KELIR KULON PROGO
}

\author{
Oleh: \\ Danang Try Purnomo \\ STAB Negeri Raden Wijaya Wonogiri \\ danangtrypurnomo@gmail.com
}

\begin{abstract}
Abstrak
Penelitian ini mengangkat tentang khazanah leksikon pertanian bahasa Jawa (BJ) dalam dinamika tutur masyarkat Buddha di Dusun Gunung Kelir Kabupaten Kulon Progo Tujuan penelitian ini adalah mendeskripsikan bentuk dan makna leksikon pertanian dalam dinamika tutur BJ masyarakat Buddha serta relevansinya dengan implikasi perubahan ekologi dalam dinamika tutur BJ di wilayah tersebut. Jenis penelitian ini adalah penelitian kualitatif. Bentuk penelitiannya adalah deskriptif dengan pendekatan ekolinguistik. Hasil dari penelitian ini adalah, pertama, pemerolehan leksikon dalam bentuk lema berupa kata dan frasa. Kedua, lekikon yang dihasilkan merujuk pada beberapa klasifikasi, yaitu leksikon yang berkaitan dengan cara kerja pertanian, leksikon yang berhubungan dengan kebendaan dan peralatan pertanian, leksikon yang berhubungan dengan hasil pertanian, leksikon yang berhubungan binatang, dan leksikon yang berhubungan dengan keadaan lingkungan. Ketiga, eksistensi penggunaan bahasa Jawa ragam pertanian merepresentasikan kelestarian lingkungan yang relatif masih terjaga. Hal ini dipengaruhi oleh ketergantungan masyarakat yang masih menggantungkan kehidupan melalui pertanian. Akan tetapi, potensi keterancaman ragam tutur pertanian tetap masih ada karena pewarisan profesi bertani kepada generasi penerus yang cenderung menurun dan pengaruh pertumbuhan penduduk dan kemajuan teknologi yang turut menggeser fungsi lahan.
\end{abstract}

Kata kunci: leksikon pertanian, ekolinguistik, kelestarian lingkungan

\begin{abstract}
This study raised about the treasures of Javanese agricultural lexicon in the dynamics of Buddhist community speech in Gunung Kelir village Kulon Progo district. The purpose of this research is to describe the shape and meaning of the agricultural lexicon in the dynamics of Javanese speech of Buddhist society and its relevance to the implications of ecological changes in the dynamics of Javanese speech in the region. This type of research is qualitative research. The form of research is descriptive with ecolinguistic approach. The result of this study is, first, the acquisition of lexicon in the form of glue in the form of words and phrases. Second, the resulting lexicon refers to several classifications, namely the lexicon related to the workings of agriculture, the lexicon related to the materials and agricultural equipment, the lexicon related to agricultural products, the animalrelated lexicon, and the lexicon related to environmental conditions. Third, the existence of the use of Javanese language of agricultural variety represents a relatively maintained environmental sustainability. This is influenced by the dependency of people who still depend on life through agriculture. However, the potential for threat of various agricultural speech still exists because of the devolution of the farming profession to the next generation that tends to decrease and the influence of population growth and technological advances that help shift the function of land
\end{abstract}

Keywords: agricultural lexicon, ecolinguistics, environmental sustainability 


\section{PENDAHULUAN}

Keberlangsungan interaksi dalam suatu masyarakat dapat dilihat dengan adanya penggunaan bahasa. Segala kegiatan masyarakat akan baik jika adanya proses interaksi dan komunikasi. Proses interaksi dan komunikasi terjadi karena adanya bahasa yaitu sebagai alat komunikasi yang digunakan oleh setiap anggota masyarakat. Bahasa digunakan dalam setiap kegiatan masyarakat, seperti dalam Chaer dan Agustina (2010) yang mengatakan bahwa setiap kegiatan kemasyarakatan manusia, mulai dari upacara pemberian nama bayi yang baru lahir sampai upacara pemakaman jenazah tidak terlepas dari penggunaan bahasa. Kemampuan seseorang dalam melakukan interaksi dengan lingkungannya akan dipengaruhi oleh kemampuannya dalam menggunakan sistem bahasa yang berkembang dalam lingkungan tempat tinggalnya. Dalam hal ini, bahasa dan lingkungan adalah dua entitas yang tidak dapat dipisahkan dalam konteks kehidupan sosial bermasyarakat.

Terkait dengan kajian bahasa dan lingkungannya, studi linguistik dan ekologi merupakan studi interdisipliner yang dIkenal dengan kajian ekolinguisti. Ekolinguistik adalah suatu disiplin ilmu yang mengkaji lingkungan dan bahasa. Oleh karenanya, bahasa sangat berkaitan erat dengan dengan lingkungannya sendiri. Suatu bahasa juga berkemungkinan punah apabila ekologi yang menunjangnya punah. Menurut Yusradi Usman (2010) dalam tulisannya "Mengenal Linguistik", Ekolinguistik merupakan perpaduan ekologi dan linguistik yang merupakan sebuah kajian baru dalam ranah linguistik di Indonesia. Secara ringkas ekolinguistik melihat kedudukan, peran, fungsi, keterkaitan serta keterpengaruhan ekologi dengan linguistik dan sebaliknya. Di sini dapat dilihat adanya hubungan yang nyata dan erat perihal bahasa yang dipakai manusia terhadap kelestarian dan kerusakan lingkungan.

Berkenaan dengan hal-hal tersebut leksikon dari suatu bahasa terbentuk dari keadaan fisik lingkungan yang didiami oleh suatu masyarakat. Terdapat beraneka ragam seperti masyarakat nelayan, pertanian, hutan,
perDusunan, pegunungan dan lain sebagainya. Fenomena kebehasaan yang dilihat dari perspektif lingkungan bagaimana antara bahasa dan lingkungan itu dapat "hidup" secara bersinergi dan berkesinambungan. Manakala sebuah lingkungan itu rusak karena medernisasi atau bencana alam, yang terjadi adalah hilangnya leksikon yang terkait lingkungan itu digunakan oleh para generasi penerusnya. Sehubungan dengan hal tersebut, penulis tertarik untuk mengkaji fenomena kebahasaan yang digunakan masyarakat Buddha di Dusun Gunung Kelir Kabupaten Kulon Progo yang notabene sebagian masyarakatnya bermata pencaharian sebagai petani. Namun demikian, seiring perkembangan zaman dan kemajuan teknologi secara perlahan akan berpengaruh pada perkembangan kebahasaaan terutama terkait istilah-istilah yang berkenaan di bidang pertanian. Pada generasi peneru yang tidak lagi bergelut di bidang pertanian akan berpengaruh juga dalam penguasaan kebahasaan leksikonleksikon pertanian. Oleh sebab itu, bukan tidak mungkin di masa mendatang akan terjadi kepunahan ragam bahasa pertanian manakala lingkungan telah lenyap sehingga perlu adanya upaya pemertahanan bahasa. Pemertahanan pada bahasa itu dapat diamati pada tataran leksikon. Alasannya, kelengkapan leksikon dari suatu bahasa mencerminkan sebagian besar karakter lingkungan ragawi dan karakteristik sosial serta budaya masyarakat penuturnya. Sapir dalam Fill dan Muhlhausler (2001:2) juga menambahkan bahwa dalam lingkup ekolinguistik, hubungan bahasa dan lingkungannya ada pada tataran leksikon saja, bukan, misalnya, pada tataran fonologi atau morfologi.

Penelitian terhadap bahasa daerah dalam kaitannya leksikon dan lingkungan telah banyak dilakukan, seperti di antaranya penelitian yang dilakukan oleh Pilgrim (2006) dengan judul $A$ Cro sCultural Study into Local Ecological Knowledge yang berlokasi, yaitu Inggris, India, dan Indonesia dengan fokus kajian bagaimana masyarakat memahami hubungan, kedekatan, dan ketergantungan mereka dengan alam sebagai sumber penghidupan. Temuan Pilgrim (2006) dijadikan 
acuan dalam konsep tentang faktor-faktor yang melatarbelakangi punahnya leksikon-leksikon tentang pemahaman dan pengetahuan responden terhadap leksikon lingkungan alam. Penelitian dengan judul Lnguistic Erotion on the Chesapeak: Intergenerational Diachronic Shifts in the Lexicalization of the Bay adalah oleh Pandey (2007) yang dimuat dalam Jurnal Language and Ecology Vol.2: 3 dengan fokus kajian, yakni pergeseran leksikalisasi sebuah ungkapan lokal "across the bridge". Pengelompokan umur responden dalam kajian Pandey (2007) dijadikan acuan dalam penelitian ini.

Sementara itu, Rasna (2010) dengan penelitiannya yang berjudul Pengetahuan dan Sikap Remaja terhadap Tanaman Obat Tradisional di Kabupaten Buleleng: Sebuah Kajian Ekolinguistik mengetes pengetahuan leksikon dan pengetahuan manfaat responden terhadap 11 tanaman obat. Cara analisis data yang dilakukan Rasna adalah dengan mendeskripsikan istilah-istilah dalam obat tradisional dan turunannya dipakai sebagai pijakan dalam analisis data penelitian ini. Selanjutnya, Sukharani (2010) melakukan penelitian dengan judul Leksikon Nomina Bahasa Gayo dalam Lingkungan Kedanauan Lut Tawar: Kajian Ekolinguistik penelitian dilakukan dengan cara menguji coba pengetahuan responden terhadap 360 leksikon nomina tentang lingkungan ragawi Danau Lut Tawar tentang (1) nama-nama ikan dan hewan yang hidup di dalam danau dan alirannya, (2) nama-nama burung, hewan, dan padi di lingkungan danau, (4) nama-nama bendabenda mati yang ditemukan di dalam dan lingkungan danau, (5) nama-nama alat penangkap ikan tradisional dan penggemukan ikan di lingkungan danau, dan (6) kebertahanan bahasa dan budaya Gayo yang terkait dengan kelestarian lingkungan Danau Lut Tawar.

Bang \& Doors (dalam Lindo dan Bundesgaard, ed.,2000:10-11) mengatakan bahwa bahasa merupakan bagian dari sebuah aktivitas sosial yang terkandung dan mengandung praksis sosial (social praxis). Praksis sosial adalah sebuah konsep yang mengacu pada semua tindakan, aktivitas, perilaku masyarakat, baik sesama anggota masyarakat (lingkungan sosial) maupun terhadap lingkungan alamnya. Bahasa dan praksis sosial merupakan dua hal yang berkaitan erat. Dalam hal ini praksis sosial merupakan aspek yang mendominasi, sedangkan bahasa merupakan aspek yang didominasi. Hal ini mengindikasikan bahwa perubahan praksis sosial (perubahan tindakan, aktivitas dan perilaku manusia terhadap sesama dan juga terhadap lingkungan alamnya) menimbulkan perubahan pada bahasa atau perubahan praksis sosial merupakan penyebab perubahan bahasa dan yang paling mudah diamati adalah perubahan pada tataran leksikon.

Praksis sosial melingkupi tiga dimensi (triple dimensions), yakni (1) dimensi ideologis, yaitu ideologi yang berhubungan dengan tatanan mental individu atau masyarakat, kognitif, dan psikis yang melekat pada masyarakat tutur; (2) dimensi sosiologis adalah dimensi yang berkaitan dengan bagaimana masyarakat tutur menata, mengorganisasikan, dan mengomunikasikan interaksi mereka dengan sesama sehingga muncul rasa kebersamaan, saling mengasihi, saling membutuhkan dan pada akhirnya memunculkan rasa penghargaan terhadap sesama; dan (3) dimensi biologis adalah dimensi yang berkenaan dengan keberadaan manusia secara biologis bersanding dengan spesies lain, yang identik dengan adanya keberagaman (diversity) baik hewan maupun tumbuhan, secara berimbang dalam sebuah ekosistem yang secara verbal terekam dalam leksikon bahasa sehingga entitas-entitas itu tertandakan, dikenal, dan kemudian dipahami.

Teori kedua yang diterapkan dalam kajian ini adalah teori perubahan bahasa yang dikemukakan oleh Labov (1994) dan Aitchison (1991). Kedua ahli bahasa ini mengemukakan bahwa perubahan bahasa secara garis besar disebabkan oleh dua faktor, yakni faktor internal dan eksternal kebahasaan. Labov (1994) yang pada dasarnya mengungkapkan bahwa perubahan bahasa sering diawali dengan penyimpangan-penyimpangan dari normanorma baku pemakaian bahasa yang biasanya terjadi secara perlahan-lahan (evolutive) dan diawali oleh sesuatu yang kecil yang terjadi saat ini disebut oleh Labov (1994) dengan istilah language change in progress. Selanjutnya, Labov (1994) menyebutkan 
bahwa penyebaran perubahan bahasa menyangkut dua hal, yakni penyebaran terkait dengan internal kebahasaan yang menyangkut unsur-unsur kebahasaan tersebut.

Teori ketiga yang diterapkan untuk mengkaji masalah penelitian ini adalah teori semantik yang terkait dengan konsep dan cara penamaan entitas-entitas acuan dalam leksikon bahasa Jawa. Terkait dengan konsep dijelaskan bahwa secara secara teoretis, hal yang paling mendasar pada anggota masyarakat dalam penguasaan nomenkaltur ialah mengenali dan/atau memahami nama-nama lingkungan alam khususnya sektor pertanian dalam masyarakat tutur tersebut. Pengenalan dan pemahaman tersebut dapat dibedah dengan menggunakan teori "Segitiga makna" dari Ogden dan Richardas (periksa Ullmann, 1985: 55). Sebab, gagasan teori makna itu bertolak dari penunjukkan nama-nama (nomenklatur) lingkungan alam itu dengan hal di luar nama (lambang), yakni benda-benda (things) itu sendiri. Dengan kata lain, penunjukkan namanama itu bersifat ostensif, menunjuk dengan telunjuk jari. Oleh karen itu, teori makna yang demikian dinamakan Teori Referensial (Saeed, 2000:67).

Apabila dihubungkan dengan dinamika pemahaman dan penggunaan antargenerasi masyarakat tutur BJ terhadap kelompok leksikon lingkungan alam khususnya pertanian, maka secara teoritis yang berperan adalah nama-nama benda yang sudah menjadi pengetahuan itu. Jadi, kajian teoretis dari sudut pemahaman makna atas leksikon pertanian BJ tidak membutuhkan waktu lama saat seorang anak mulai dalam pemerolehan nomenklatur yang menjadi objek penelitian ini. Persoalannya ialah nama-nama benda itu sudah menjadi pengetahuan mereka meskipun entitas acuannya sudah tidak ditemukan lagi di sekliling mereka. Terkait dengan penamaan Saeed (2000:27) mengatakan bahwa nama pada dasarnya merupakan label-label, di antaranya untuk melabelkan manusia, tempat, hewan, tumbuhan dan benda.

Pemertahanan pada bahasa itu dapat diamati pada tataran leksikon. Alasannya, kelengkapan leksikon dari suatu bahasa mencerminkan sebagian besar karakter lingkungan ragawi dan karakteristik sosial serta budaya masyarakat penuturnya. Sapir dalam Fill dan Muhlhausler (2001:2) juga menambahkan bahwa dalam lingkup ekolinguistik, hubungan bahasa dan lingkungannya ada pada tataran leksikon saja, bukan, misalnya, pada tataran fonologi atau morfologi. Berdasarkan hal tersebut penulis mengkaji fenomena kebahasaan pada mayarakat tutur bahasa Jawa pada umat Buddha di Dusun terebut khususnya dilihat dari perspektif ekolinguistik, yakni keterjalinan antara bahasa dan lingkungan pertanian di wilayah tersebut.

\section{METODE}

Penelitian ini termasuk jenis penelitian dekriptif kualitatif. Disebut kualitatif karena penelitian ini bertujuan untuk memahami fenomena-fenomena kebahasaan yang terjadi dan tidak terkait dengan perhitungan angka sebagai hasil akhir (Mahsun, 2005: 233). Penelitian deskriptif berusaha memahami makna dari fenomena-fenomena, peristiwaperistiwa dan kaitannya dengan orang-orang atau masyarakat yang diteliti dalam konteks kehidupan dalam situasi yang sebenarnya (Subroto, 2007:6). Sesuai dengan pernyataan tersebut, penelitian ini bertujuan memahami fenomena tertentu, khususnya penggunaaan bahasa dalam khazanah leksikon pertanian masyarakat tutur BJ.

Teknik pengumpulan data dalam penelitian ini adalah simak yang diawali dengan pengamatan (observasi) dan cakap (wawancara). Dalam mengaplikasikan teknik menyimak ini digunakan teknik dasar sadap dan teknik lanjutan simak libat cakap, rekam, catat, dan kerja sama (Sudaryanto, 2015). Teknik sadap yaitu menyadap penggunaan bahasa dari objek penelitian dengan cara mengerahkan segenap kemampuan dan pikiran menyadap pemakaian bahasa di masyarakat. Teknik sadap ini dipakai untuk mendapatkan data dari informan secara spontan dan wajar. Teknik rekam didapatkan dengan cara merekam pemakaian bahasa lisan yang bersifat spontan. Hal ini berfungsi untuk mengabadikan data dari hasil wawancara dengan informan, mendapatkan data sesuai dengan tujuan penelitian, dan merekam secara wajar terhadap satuan lingual. Teknik catat adalah proses memperoleh data dengan mencatat data kebahasaan atau istilah-istilah yang relevan 
sesuai dengan sasaran dan tujuan penelitian

Teknik kerja sama adalah melakukan interaksi secara kooperatif dengan informan atau melakukan wawancara. Informan yang diwawancarai adalah penutur asli yang berkemampuan memberi informasi kebahasaan kepada peneliti yaitu memberi informasi kebahasaan yang dikehendaki oleh peneliti dan peneliti yang merencanakan dengan pertanyaan agar terarah sesuai dengan tujuan penelitian.

\section{PEMBAHASAN}

Masyarakat tutur di Desa Gunung Kelir, Jatimulyo, Kulon Progo contoh sebuah guyup kebahasaan. Mereka menyepakati aspek-aspek kebahasajawaan dan menggunakannya secara praktis dalam berkomunikasi. Bagaimana mereka menentukan kata atau istilah dan bagaimana mereka menggunakan istilah tersebut dalam konteks yang tepat tentu juga sebuah kesepakatan. Masyarakat di Dusun Gunung Kelir secara umum berprofesi sebagai petani memiliki leksikon yang mereka gunakan dalam bidang pertanian. Leksikon tersebut mencakupi 1) leksem cara yang biasanya berupa verba yang memerikan atau menerangkan bagaimana proses kerja dalam melakukan sesuatu, dan sebagainya. 2) leksem nomina untuk menamai benda-benda yang mereka gunakan sehari-hari dalam hal bertanam, termasuk alat digunakan oleh petani, 3) leksikon yang berhubungan dengan hasil pertanian, 4) leksikon yang berhubungan dengan binatang, 5) lekikon yang berhubungan dengan keadaan lingkungan. Terpeliharanya leksikon pertanian yang digunakan dalam komunikasi masyarakat guyup tani mendeskripsikan bahwa ekologi pertanian di wilayah tersebut masih terpelihara dengan baik. Meskipun demikian tidak dapat dipungkiri pesatnya laju pembangunan membuat ketersediaan lahan pertanian semakin berkurang yang secarea perlahan pada masa yang akan datang membuat leksikon-leksikon pertanian itu tidak lagi digunakan oleh para penuturnya.

Berikut adalah bentuk-bentuk satuan lingual dan makna yang terkandung dalam eksikon pertanian masyarakat guyup tutur di Desa Gunung Kelir, Jatimulyo, Kabupaten
Kulon Progo

\section{Bentuk-Bentuk Leksikon dalam Dinamika Tutur BJ}

\begin{tabular}{|c|c|}
\hline $\begin{array}{l}\text { Ruang Lingkup } \\
\text { Leksikon }\end{array}$ & Lema \\
\hline $\begin{array}{l}\text { Leksikon yang } \\
\text { berhubungan } \\
\text { dengan cara kerja } \\
\text { (verba) pertanian }\end{array}$ & 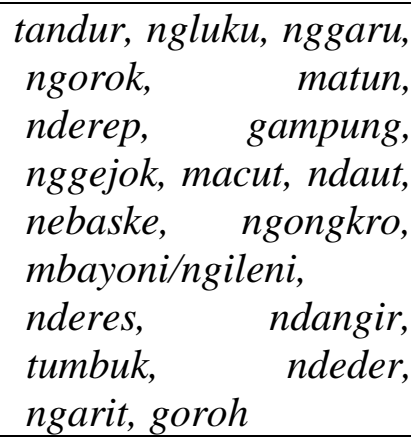 \\
\hline $\begin{array}{l}\text { Leksikon yang } \\
\text { berhubungan } \\
\text { dengan kebendaan } \\
\text { (nomina) dan } \\
\text { perlatan pertanian }\end{array}$ & $\begin{array}{l}\text { Luku, garu, winih, } \\
\text { blak, korok, damen, } \\
\text { baron, } \\
\text { galeng/galengan, } \\
\text { peret, pacul, alu } \\
\text { pancong, alas, petani } \\
\text { gilo klopo, tegalan, } \\
\text { bumbu masak, pakan, } \\
\text { siti wiyar, uwit, suket, } \\
\text { godhong, lesung, } \\
\text { rabuk, sabin, } \\
\text { bumbung, sakalcagak, } \\
\text { lempung }\end{array}$ \\
\hline $\begin{array}{l}\text { Leksikon yang } \\
\text { berhubungan } \\
\text { dengan hasil } \\
\text { pertanian }\end{array}$ & $\begin{array}{l}\text { Pari/pantun, } \text { gabah, } \\
\text { uwos, panili, nira, } \\
\text { kopi, cengkeh, kakao, } \\
\text { palawija, sayor, katul, } \\
\text { jenang katul, tela } \\
\text { pendhem, gaplek, pari } \\
\text { gogo }\end{array}$ \\
\hline $\begin{array}{l}\text { Leksikon yang } \\
\text { berhubungan } \\
\text { dengan binatang di } \\
\text { sekitar pertanian }\end{array}$ & $\begin{array}{l}\text { Sundep, wereng, ama, } \\
\text { semut abang/abrit, } \\
\text { ndoler, walang, ondol- } \\
\text { ondol, pedhet/sapi, } \\
\text { manuk, tikus, } \\
\text { ulo/sawer, mendo } \\
\text { (gembel/jawa), }\end{array}$ \\
\hline $\begin{array}{l}\text { Leksikon yang } \\
\text { berhubungan } \\
\text { dengan keadaan } \\
\text { lingkungan di } \\
\text { sekitar pertanian }\end{array}$ & $\begin{array}{l}\text { Legok, mabul, nelo, } \\
\text { puther, uwoh/awoh, } \\
\text { tadah udan, tumpang } \\
\text { sari, rendeng, ketigo }\end{array}$ \\
\hline
\end{tabular}




\section{Makna Lekikon Pertanian dalam Dinamika Tutur BJ}

Leksikon yang berhubungan dengan cara kerja pertanian:

1) Leksem tandur atau nandur

Lema tandur sudah masuk dalam Kamus Besar bahasa Indonesia yang diartikan 'kegiatan mananam padi dan sebagainya.

2) Lema ngluku

Kata luku berasal dari bentuk dasar luku. Lema luku sudah masuk Kamus Besar Bahasa Indonesia dan disinonimkan dengan bajak dan tenggala. Aktivitas membajak sawah sebelum masa tanam padi inil yang disebut $n g l u k u$

3) Lema nggaru

Kata nggaru berasal dari bentuk dasar garu. Lema garu juga sudah menjadi bagian dari Kamus Besar Bahasa Indonesia. Garu terbuat dari besi dan berbentuk seperti sisir besar.

4) Lema ngorok

Kata ngorok berasal dari bentuk dasar korok. Dalam Kamus Besar Bahasa Indonesia kata ini dimaknai sebagai 'lubang atau liang memanjang (dalam tanah); tembusan; terowongan.' Kata ngorok dimaknai sebagai aktivitas mengatur kembali jarak antartanaman padi supaya rapi.

5) Lema matun

leksem matun sudah dimasukkan dalam Kamus Besar Bahasa Indonesia dan bermakna 'menyiangi gulma di sawah atau tegalan.'

6) Lema nderep

Dalam bahasa Jawa lema nderep dimaknai sebagai kegiatan memanen. Aktivitas ini biasanya dilakukan oleh sekelompok orang yang terdiri atas pria dan wanita. Dalam Kamus Besar Bahasa Indonesia kata nderep merupakan bentuk dasar dari lema derep yang berarti 'menolong memotong padi.

7) Lema gampung

Kata gampung mengacu kepada aktivitas memunguti sisa-sisa hasil panen..

8) L ema nggejog

Kata nggejog dapat diartikan aktivitas merontokkan atau melepaskan bulirbuliran padi dari tangkainya (damen) dengan

menginjak-injaknya menggunakan kedua kaki.

9) Lema macul

Lema macul berasal dari bentuk dasar nomima pacul berarti'alat untuk menggali dan mengaduk tanah, dibuat dari lempeng besi dan diberi tangkai panjang untuk pegangan..

10) Lema ndaut

Leksem ndaut diartikan 'mengambil benih padi dari persemaian' kemudian diikat dengan bambu dan ditata rapi dipinggir sawah..

11) Lema nebaske

Kata nebaske berasal dari bentuk dasar tebas yang dalam Kamus Besar Bahasa Indonesia diartikan 'borong hasil panen.

12) Lema mbanyoni atau ngileni

Istilah mbanyoni dapat diartikan sebagai aktiitas 'menambah air ke sawah dari irigasi secara bergiliran.

13) Lema nderes

Nderes adalah aktivitas mengambil getah atau cairan dari pohon aren..

14) Lema ndangir

Leksem ndangir adalah verba, sedangkan bentuk dasarnya adalah dangir. Lema dangir sudah masuk dalam kamus besar bahasa Indonesia yang dalam bentuk verbanya mendangirr atau ndangir berarti akttivitas mencangkuli tanah (dengan cangkul kecil) dan membersihkannya sepaya tanah tetap subur.

15) Lema tumbuk

Lema tumbuk diartikan aktivitas mengupas padi dari kulitnya dengan menggunakan antan atau alu.

16) Lema ndeder

Kata ndeder dalam konteks pertanian atau tanaman berarti aktivitas menyebar benih atau biji tanaman ke dalam uatu lahan dengan jarak tanam lebih rapat untuk mendapatkan hasil maksimal.

17) Lema ngarit

Ngarit berasal dari kata dasar arit, yaitu benda tajam yang biasanbya untuk memangkas semak-semak, dedauan, dan pohon. Dalam bahasa Indonesia diebut sabit. Kegiatan ngarit ini sudah identik dilakukan masyarakat yakni mencari daun-daun atau rumputatau tanaman sejenis yang akan dipergunakan untuk 
pakan ternak.

18) Lema goroh

Kata goroh dalam bahasa Indoneia diartikan 'menyembelih,' yakni aktivitas menyembelih hewan ternak seperti sapi dan kambing.

Leksikon yang berhubungan dengan kebendaan dan peralatan pertanian:

1) Lema winih

Kata winih dapat diartikan benih, yaitu bibit padi yang siap disemai.

2) Lema damen

Lema damen atau dalam bahasa Indoneia 'jerami' dikenal dengan istilah dami oleh penutur bahasa Jawa. Kata damen dan dami sudah menjadi bagian dari Kamus Besar Bahasa Indonesia.

3) Lema galengan

Kata galeng dalam bahasa Indonesia disebut 'pematang' dan merupakan kata generik dalam ihwal bertanam padi. Galeng mengacu kepada gundukan tanah yang dibuat membujur dan melintang yang selain berfungsi menahan air irigasi supaya tidak mengalir ke luar, juga berguna sebagai pembatas lahan persawahan.

4) Lema alas

Kata alas sudah masuk dalam Kamus Besar Bahasa Indoneia yang diartikan hutan.

5) Lema petani gulo klopo

Istilah petani gulo klopo digunakan untuk menyebut nama lain dari petani gula aren. Para petani di desa wilayah tersebut dapat menjadi petani gulo klopo atau sebutan petani lainnya bergantung dari muim panen yang sedang dihadapi.

6) Lema sabin

Lema sabin adalah sebutan bahasa Jawa kromo alus untuk lahan sawah.

7) Lema tegalan

Bentuk dasar tegalan yakni tegala yang memiliki makna tanah yang realif luas utnuk ditanami jenis palawija dan biasanya tidak menggunakan sistem irigasi.

8) Lema rabuk

Lema rabuk sudah masuk dalam Kamus

Besar Bahasa Indonesia yang diartikan pupuk.
9) Lema alu

Lema alu sudah masuk dalam lekikon bahasa indonesia yakni suatu alat yang berbentuk lonjong bulat dan digunakan untuk menumbuk padi.

10) Lema lesung

Kata lesung sudah masuk dalam leksikon bahasa Indonesia, yaitu lumpang kayu yang panjang yang biasanya digunakan sebagai wadah untuk menumbuk padi dan sebagainya..

11) Lema pakan

Istilah pakan meripakan ebutan untuk bahan makanan yang dikonsumsi hewan ternak.

12) Lema siti wiyar

Frasa siti wiyar merupakan gabungan dari lema siti yang berarti 'tanah' atau 'lemah' dan wiyar (krama alus) yang berarti 'luas' atau 'amba' dalam bahasa Jawa.

13) Lema blumbang

Kata blumbang dapat diartikan wadah atau tempat untuk menampung air..

14) Lema suket

Kata suket dalam bahasa Indonesia berarti rumput. Suket dimanfaatkan petani sebagai pakan ternak.

15) Lema godhong

Godhong dalam bahasa Indonesia diartikan daun. Dalam kahanah pertanian godhong dapat berfungsi sebagai hasil pohok yang dimanfaatkan seperti halnya sayuran, tetapi dapat pula sebagai penghasil tambahan seperti godhong gedhang 'daun pisang' godhong kelapa atau janur.

16) Lema saka

Kata saka atau cagak dalam bahasa Indonesia diartikan tiang.

17) Lema uwit

Dalam percakapan masyarakat lebih sering mengucapkan wit atau wit-witan yang berarti pohon dan pepohonan bentuk jamaknya.

18) Lema lempung

Dalam bahasa indonesia kata lempung diartikan 'tanah liat,' yakni jenis tanah yang relatif lebih lentur dan berwarna hitam.

19) Lema sajen

Dalam bahasa Indonesia istilah sajen dimaknai dengan 'sesaji.' Sajen atau 
sesaji merujuk sesuatu yang disajikan untuk memohonkan sesuatu kepada sang Pencipta.

20) Lema ubo rampe

Sama halnya dengan sajen, istilah ubo rampe merujuk pada sarana yang digunakan untuk pelengkap ritual.

Leksikon yang berhubungan hasil pertanian:

1) Lema pari

Dalam bahasa Jawa kata pari atau pantun sudah sangat populer dikenal masyarakat yang dalam bahasa Indoneia disebut padi.

2) Lemah gabah

Lema gabah sudah dimasukkan dalam kamus Bear Bahasa Indonesia. Gabah adalah butiran padi yang sudah lepas dari tangkainya dan masih berkulit.

3) Lema panili

Masyarakat Jawa sering menyebutnya panili, tetapi dalam bahasa Indonesia ditulis vanili. Vanili memiliki arti tanaman menjalar yang buahnya berbentuk polong; berisi biji harum yang dikeringkan dan biasanya digunakan sebagai pengharum makanan.

4) Lema nira

Nira sering dilafalkan niro adalah getah atau cairan manis yang didapatkan dari hasil men-nderes pohon aren.

5) Lema kopi

Kata kopi sama dalam bahasa Indonesia yakni jenis pohon yang bijinya ditumbuk dan diolah sedemikian rupa sehingga menjadi serbuk merupakan bahan minuman yang dihasilkan mayarakat

6) Lema palawija

Dalam bahasa jawa seriang diucapkan polowija sebagaimana penulisannya pula. Polowijo adalah jeni tanaman selain padi yang di tanam di ladang atau tegalan seperti kacang, jagung, ubi-ubian dan lain-lain.

7) Lema kakao

Kakao merupakan salah satu dari jenis tanaman yang dihasilkan petani yang berupa biji dan masyarakat secara lazim menyebutnya cokelat.

8) Lema tela pendem

Kata tela dalam bahasa Indonesia ketela yakni tanaman umbian. Sementara itu, pendhem berarti berada di dalam tanah atau terkubur sehingga tela pendhem merujuk pada jenis umbi yang buahnya tertanam di dalam tanah..

9) Lema katul

Padi yang telah ditumbuk sehingga leba dari kulitnya menyisakan butiran lembut halus yang disebut katul..

10) Lema jenang katul

Sama halnya dengan katul fraa jenang katul ini merujuk pada katul yang telah diolah sedemikian rupa dan ditambahkan cairan dan menjadi lembek seperti bubur sehingga sering disebut dengan jenang katul.

11) Lema tela

Lema tela atau telo penyebutannya dalam bahasa Jawa, sedangkan dalam bahasa Indoneia disebut ketela.

12) Lema mendho atau wedhus

Selain hasil pertanian, para petani juga membudidayakan ternak. Ternah yang dibudidayakan adalah mendho atau wedhus yang dalam bahasa indonesia disebut kambing.

13) Lema semut abang atau semut abrit

Istilah emut abang atau semut abrit adalah jeni hewan erangga yang dikategorikan sebagai hama.

14) Lema ondol-ondol

Jenis hama lain yang ditemukan dalam pertanian adalah ondol-ondol. Ondolondol ini adalah hama yang berjenis ulat menyerang pada daun sehingga menjadi mengkerut.

Lekikon yang berhubungan dengan keadaan lingkungan di sekitar pertanian:

1) Lema legok

Kata legok dalam Kamus Besar Bahasa Indonesia berkelas kata sifat dan bermakna lekuk; cekung; lebih dalam atau rendah dari tempat lain (tanah, lembah, dan sebagainya)..

2) Lema mabul

Istilah mabul digunakan untuk menyebut suatu kondisi padi yang sudah mulai menghijau.

3) Lema nelo

Lema nelo dapat dimaknai suatu keadaan tanah yang retak-retak atau memiliki rongga yang memanjang..

4) Lema puther: 
Lema puther dalam pertuturan digunakan untuk merujuk pada kondisi daun yang tidak tumbuh normal, yakni mengkerut.

5) Lema tadah udan

Kata tadah dapat diartikan 'wadah' atau suatu tempat, sedangkan udan berarti 'hujan.' Frasa tadah udan digunakan untuk merujuk pada lahan pertanian yang hanya memanfaatkan air hujan sebagai sumber mata air untuk mengelola lahan pertaniannya.

6) Lema $u w o h$

Kata uwoh dalam bahasa Indonesia berarti berbuah. Penuturan uwoh biasanya merujuk pada tanaman-tanaman yang diambil buahnya seperti alpukat, pisang, mangga dan jambu.

7) Lema tumpang sari

Tumpang sari merupakan lema yang sudah terdaftar dalam Kamus Besar Bahasa Indonesia. Istilah ini sudah lazim digubnakan dalam masyarakat guyub tutur pertanian. $\mathrm{T}$

8) Lema ranggas

Kata ranggas merujuk kondisi pada musim kemarau, yakni uatuu keadaan pepohonan yang udah mengering sehingga daun-daunnya kering danb berguguran.

\section{Relevansi antara Linguistik dan Ekologi dengan Dinamika Tutur BJ}

Eksistensi bahasa memiliki peran dan pengaruh terhadap keberlangsungan dan keseimbangan lingkungan yang perlu dijaga dan dipelihara. Karena itu, perubahan berbagai bentuk dan fungsi lingkungan dapat juga diamati dan direkam dalam bahasa. Selain itu, bahasa merupakan gambaran identitas, merekam kearifan lokal, konsepkonsep kolektif, nilai-nilai historis, religious, filosofi, sosiobudaya, dan ekologis dari suatu masyarakat. Oleh sebab itu, yang diperlukan masyarakat penutur bahasa bukan hanya sebuah kognisi atau pengetahuan, tetapi diperlukan juga sebuah kompetensi dan performansi yang komunikatif, produktif dan kreatif baik lisan maupun tulisan dengan kekayaan rana pakai bernuansa etnis (Halliday dan Ruqaiya, 1978:10).

$$
\text { Tingkatan pengetahuan dan }
$$

pemahaman leksikon pertanian dalam dinamika tutur bahasa Jawa masyarakat di Dusun Gunung Kelir dipengaruhi oleh pengetahuan terhadap lingkungan (ekologi) tersebut. Maka dari itu, masyarakat setempat sebagai pemilik dan pengguna telah berinterelasi dan berinteraksi dengan lingkungannya sehingga memiliki pengetahuan, konsep, tata nilai dan ideologi yang lahir dan terbangun dalam komunitas lingkungannya pula khuusnya pengetahuan leksikon-leksikon pertanian.

Keadaan dan eksistensi lingkungan ragawi sangat memengaruhi kekayaan alam dan juga tingkat pengetahuan masyarakat Dusun Gunung Kelir tentang objek atau benda yang ditemui. Pengenalan, pengetahuan, dan pemahaman yang mendalam adalah fakta interaksi, interelasi, dan interdepedensi masyarakat setempat sebagai penutur bahasa bahasa Jawa dengan lingkungan pertanian itu dikodekan secara lingual dalam wujud leksikon-leksikon pertanian.

Bahasa dapat hidup atau mati tergantung pada penggunaan dan berkembang atau tidaknya suatu bahasa. Berkembang dan menyusutnya suatu bahasa tentu dipengaruhi oleh berbagai faktor. Hal ini disebabkan bahasa hidup dalam lingkungan sosial suatu masyarakat penutur untuk berinteraksi, interdepedensi, dan interelasi dengan lingkungan. Suatu bahasa tetap bertahan dan hidup, jika penuturnya selalu menggunakan bahasa tersebut. Dengan demikian, bahasa itu akan terjaga dan tetap berada dalam pikiran atau kognisi penuturnya. Leksikon itu dapat bertahan dan atau menyusut, bergeser bahkan hilang atau punah dapat dipengaruhi oleh berbagai faktor yang terjadi di dalam masyarakat.

Berdasarkan hasil interaksi dan wawancara dengan narasumber terdapat faktor-faktor yang memengaruhi dinamika tutur bahasa Jawa dalam perkembangan leksikon pertanian. Terdapat dua faktor yang menyebabkan bertahannya leksikon pertanian dalam bahasa Jawa. Pertama, keberadaan sumber penghidupan masyarakat Dusun Gunung Kelir yang masih lestari. Masyarakat Dusun Gunung Kelir umumnya menggantungkan hidup sepenuhnya pada alam sekitarnya, termasuk lingkungan 
pertanian yang menjadi penopang hidup sehari-hari. Kondisi ini menyebabkan masyarakat mengenal dan mengakrabi seputar cara bertani, hasil tani, tumbuh-tumbuhan, hewan ternak dan sebagauinya. Kondisi ini memberikan manfaat secara langsung maupun tidak langsung bagi kehidupan mereka dan akhirnya leksikon-leksikon itu terkonsep ke dalam kognisi atau pikiran mereka.

Kedua, kondisi lingkungan yang sebagian besar masih terjaga dengan baik sehingga referen tentang aktivitas pertanian, tumbuhan, hewan dan berbagai peralatan penunjang itu masih ada di lingkungan. .Oleh karena itu, betrbagai leksikon yang mendukung seputar pertanian masih dapat dilihat, dan dimanfaatkan masyarakat. Kondisi seperti ini tentu sangat berbeda pada lingkungan perkotaan yang hal-hal terebut sudah tidak ditemukan sehingga dapat hilang dalam pikiran individu.

Sementara itu, berkuranya leksikonleksikon pertanian dalam dinamika tutur BJ juga dipengaruhi oleh beberapa faktor dan keadaan, seperti berikut. Pertama, proses penerusan atau transfer dari generasi tua ke generasi muda yang kurang. Maksudnya adalah leksikon-leksikon maupun referen dari pertanian, tumbuhan, hewan dan peralatan tradisional yang tidak ditransfer atau diteruskan dari generasi tua ke generasi muda menyebabkan tidak terkonsep dalam pikiran generasi muda tentang leksikon maupun referen dari beragam leksikon itu. Hal ini mengakibatkan leksikon maupun referenseputar dunia pertanian dapat menyusut bahkan hilang dari pikiran penutur terutama pada generasi muda.

Faktor kedua, terjadi migrasi penduduki terutama generasi milenial. Menurut pengakuan narasumber sudah tidak banyak anak-anak dari mereka yang melanjutkan pekerjaan sebagaimana orang tua mereka. Para generasi muda lebih memilih untuk keperluan studi maupun mencari pekerjaan di kota sehingga intensitas mereka ke rumah sangat minim, bahkan pindah domisili. Apabila hal ini berlangsung terusmenerus bukan tidak mungkin secara perlahan profei sebagai petani sudah menjadi hal yang langka sehingga akan berpengaruh terhadap eksistensi BJ ragam pertanian tersebut.
Faktor ketiga, pemakaian bahasa Indonesia yang lebih dominan dari bahasa Jawa. Dari penuturan narasumber diakui bahwa para ibu muda sudah mulai meninggalkan BJ dalam mengajarkan bahas ibu kepada anak-anaknya karena dianggap lebh praktis dan modern. Maka dari itu, kehidupan bahasa daerah perlu dilakukan refleksi dan evaluasi dalam menghadapi perubahan global yang sangat pesat. Bahasa daerah yang satu dengan bahasa daerah yang lain berbeda-beda dalam hal pertumbuhan dan pemeliharaannya. Hal ini disebabkan adanya bahasa yang terawat dengan baik atau secara aktif digunakan, dan ada juga bahasa yang tidak diperhatikan kebertahanannya atau tidak aktif digunakan. Dengan begitu, bahasabahasa daerah akan terpinggirkan karena adanya pergeseran fungsi, sikap penutur, dan tata nilai.

Faktor keempat adalah perubahan lingkungan pertanian. Tidak dapat dimungkiri bahwa perkembangan jumlah penduduk dan modernisasi di berbagai sektor kehidupan turut menggeser keberadaan lahan yang semula digunakan untuk pertanian. Dampak dari pergeseran itu adalah perubahan alih fungsi lahan. Lahan yang semula digunakan untuk bercocok tanam menjadi lahan-lahan baru seperti permukiman penduduk, gedung dan sarana pelayanan umum, dan eksplorasi lahan untuk tujuan ekowisata. Sebagian lahan yang lain beralih fungsi menjadi daerah konerasi yang dikelola negara untuk menjaga kelestarian lingkungan alam dari ancaman bencana alam seperti banjir dan tanah longsor. Perubahan lingkungan ini secara alamiah akan mereduksi pengetahuan mengenai berbagai leksikon pertanian terutama bagi genetrasi peneru yang akan datang.

\section{SIMPULAN}

Khazanah leksikon pertanian dalam dinamuka tutur bahasa Jawa masyarakat Buddha di Dusun Gunung Kelir Jatimulyo, Kabupaten Kulon Progo merupakan kekayaan bahasa daerah yang tidak dapat dipisahkan dengan eksistensi kelestarian lingkungan alam. Melalui kajian linguistik dan ekologi, keberadaan leksikonBJ ragam pertanian yang masih melekat dalam kognisi para penuturnya merepresentasikan stabilitas lingkungan yang 
relatif masih baik.

Beberapa leksikon yang terekam dari penutur terkodifikai dalam bentuk leksem dan frasa. Secara umum leksikon yang berada di wilayah sekitar dunia pertanian diklasifikasikan menjadi lima kelompok, yaitu 1) leksikon yang berkaitan dengan aktivitas cara kerja pertanian2) leksikon yang berkaitan dengan benda dan peralatan pertanian, 3) lerkikon yang berkaitan dengan berbagai hasil tani, 4) leksikon yang berhubungan dengan binatang di ekitar pertanian, dan 5) leksikon yang berkaiatan dengan sifat dan kondisi lingkungan sekitar .

Peroalan yang perlu mendapat perhatian adalah eksistensi dan kebertahanan dari leksikon itu. Perkembangan zaman lambat laun akan mengikis pengatahuan dan pemahaman masyarakat terhadap leksikonleksikon tersebut. Oleh karena itu, kajian ini dapat memberikan andil dalam uapaya mendokumentasikan pernak-pernik bahasa khusunya leksikon dalam bidang pertanian yang sangat dimungkinkan di masa yangg akan datang menuju kepunahan bahasa.

\section{DAFTAR PUSTAKA}

1. Aitchihon, Jean. 1991. Teach Yourself Linguistics London: Hodder.

2. Bang, J Chr dan Door, J. (1993). Ecolinguistics. A framework: Blackwell Publihed

3. Bundasgaards, Jeppe \& Sune Steffensen. (2000). The Diakectic of Ecological. London: Continum.

4. Fill, Alwin and Peter Muhlhauler.( 2001). The Ecolinguitic Reader Language, Ecology, and Environment. London: Continum.

5. Dil, A.S. (1972). The Ecology of Language. California:Stanford University Press

6. Gumperz, J. (1962). Antropological Linguistics. London: Longman

7. Halliday, M.A.K dan Ruqaiyah Hasan. (1976). Bahasa, Konteks dan Teks: Aspek-Aspek Bahasa dalam Pandangan Semiotik Sosial (Terjemahan oleh Asruddin Barori Tou). Yogyakarta: Gadjah Mada University Press
8. Holmes, Janet. (1992). An Introduction to Sociolinguistics. NewYork: Longman Published

9. Labov, W. (1994). Principles of Linguistic Changes olume I: Blackwel

10. Laird, CG and Robert M Gorrel. (1971). Reading About Language. Harcourt Brace Jovanovich

11. Mahsun. (2012). Metode Penelitian Bahasa: Tahapan Strategis, Metode, dan Tekniknya. Jakarta: Rajawali Pers.

12. Pandey, AK. 2007. Anti-staphyloccocal activity of a pan tropical agresive and obnoxiou weed Porihenium histerophorus: an in itro study: dalam Kumar, S and Pandey, A.K., 2013. Chemistry and biological actiitiesof falvonoid; an overview: The cientific World Jaournal

13. Pilgrim, .S. E. (2006).” A cros Culture Stidy intoLocal Ecological Knowledge (thesis). University of Essex

14. Saeed, John. (2000). Semantics. Dublin: Wiley-Blackwell

15. Subroto, Edi. (2007). Pengantar Metode Penelitian Linguistik Struktural. Surakarta: Universitas Sebelas Maret Press

16. Sudaryanto. (2015). Metode dan Teknik Analisis Bahasa: Pengantar Penelitian Wahana Kebudayaan secara Linguistik. Yogyakarta: Duta Wacana University Press.

17. Sukharani, Dewi. (2010). Leksikon Nomina Bahasa Gayo dalam Lingkungan Kedanauan lut Tawar: Kajian Ekolinguistik (tesis). Medan: Sekolah pascasarjana USU

18. Sutopo, H.B. 2002. Metodologi Penelitian Kualitatif: Dasar Teori dan Terapannya dalam Penelitian. Surakarta: Universitas Sebelas Maret Press.

19. Ullman, (1985). "Data in Search of a Theory: a Critical examination of The Relationship among Social Performance, Social Disclosure, and economic Performanceof US Firms." Academic of management Review. Vol 10, No. 3.

20. Uman, Yusradi. (2010). "Mengenal Ekolinguistik." Artikel ilmiah 